Enrico DAL COVOLO SDB

(Università Salesiana, Roma)

\title{
HOMILIA 50 JANA CHRYZOSTOMA NA EWANGELIE MATEUSZA (,Przypadek" dysproporcji egzegezy)
}

Homilia 50 Chryzostoma na Ewangelię Mateusza $a^{1}$ przedstawia interesujący „przypadek" swoistej dysproporcji egzegetycznej. W swej całości komentuje końcową perykopę 14 rozdziału św. Mateusza (w. 23-36). Jezus, po odprawieniu tłumów, spędza noc na modlitwie. Koło poranka zbliża się do łodzi uczniów krocząc po jeziorze. Także Piotr czyni parę kroków w stronę Mistrza; i on idąc po wodzie. Po chwili zaczyna tonąć. Jezus podtrzymuje go i doprowadza do lodzi, wymawiając mu jego małą wiarę. Dokonawszy przeprawy przez jezioro, Jezus przybywa do Genezaret. I tak ostatni werset - gdzie czytamy o tym, jak mieszkańcy Genezaret przynosili do Jezusa swoich chorych „,i prosili, żeby przynajmniej frędzli Jego płaszcza mogli się dotknąć" (Mt 14, 36) - pozwala Chryzostomowi rozszerzyć perspektywę parenetyczną, zasadniczo niezależną, która sama w sobie zajmuje drugą połowę homilii. W artykule zajmę się wyjaśnieniem przyczyn owej „dysproporcji egzegetycznej”, odwołując się przede wszystkim do osobowości Chryzostoma, do podstawowych cech jego przepowiadania i do właściwego mu kontekstu historyczno-teologicznego.

\section{JAN CHRYZOSTOM JAKO EGZEGETA ${ }^{2}$}

1. Kontekst historyczno-teologiczny. Jest on dobrze znany i dotyczy słynnej „szkoły” antiocheńskiej. Należy przezwyciężyć, przy tej okazji, stereotypowe

1 Odwoływać się będziemy do wydania opracowanego przez J.P. Migne'a: Commentarius in S. Matthaeum hom. 50, PG 58, 503-510; por. także najnowszy przekład włoski S. Zincone: Giovanni Crisostomo, Omelie sul Vangelo di Matteo (= Collana di testi patristici 170-172), Roma 2003, II, 350-361, zob. też przeklad polski A. Barona: Sw. Jan Chryzostom, Homilie na Ewangelię wedtug św. Mateusza, ŹMT 23, Kraków 2001, 102-110.

2 Jako wprowadzenie do dziela Chryzostoma, por. O. Pasquato, w: E. Bosio-E. Dal CovoloM. Maritano, Litroduzione ai Padri della Chiesa. Secoli III e IV (= Strumenti della Corona Patrum 3), Torino 1998², 390-435 (z bibliografią). Szczególne odniesienie do Homilii na Eıvangelię Mateu$s z a$, zob. S. Zincone, Introdızione, w: tenże (red.), Giovanni Crisostomo, Omelie sul Vangelo di 
wyobrażenic „teologii Ojców” jcdnolitej i skostniałej jakoby monolit. W rzeczywistości różnorodność starożytnych „szkól” Antiochii, Aleksandrii, Edessy, a później i Rzymu, oraz właściwych im korzeni historyczno-kulturowych, niesie w sobie zróżnicowanie myśli i wrażliwości patrystycznej. Dobrze są znane orientacje starożytnych tradycji Antiochii i Aleksandrii.

Z jednej strony Antiochia wydaje się ucieleśniać cechy tzw. „materializmu” azjatyckiego, promując dosłowne znaczenie w egzegezie i ludzką naturę Syna w chrystologii, podczas gdy Alcksandria przyjmuje raczej dwie instancje, odpowiednio się uzupełniające - alegorii w egzegezie i boskiej natury Słowa w chrystologii ${ }^{3}$. Ogólnie przyjęta jest tendencja, by uznawać Lucjana, mistrza Ariusza, za założyciela „szkoły” w Antiochii. Jednak już Ignacy w pierwszej połowie II wieku antycypował niektóre $\mathrm{z}$ jej cech charakterystycznych, przede wszystkim w wyrazistym realizmie jego wypowiedzi o naturze ludzkiej Chrystusa. W każdym razie, Chryzostom jest jednym z jej najdojrzalszych przedstawicieli.

2. Osobowość Chryzostoma. Przejdźmy więc do zilustrowania osobowości Chryzostoma. W tym celu dotkniemy najpierw jednej szczególnej kwestii jego życia. Historia jego powołania nie wydaje się być, na pierwszy rzut oka, całkiem linearna. Czując się powołanym do formy życia monastycznego i eremickiego, która $\mathrm{w}$ pierwszej połowie IV wieku zdobyła sobie wielkie powodzenie na Wschodzie ${ }^{4}$, Jan opuścił Antiochię, gdzie sprawował urząd lektora i przeniósł się na pustynne obszary góry Sylipo, niedaleko miasta. Mial nieco ponad dwadzieścia lat. Ale pobyt jego na pustyni nie trwał długo; sześć lat później, w 378 r., Jan powrócił do Antiochii.

Była to zapewne decyzja opłacona cierpieniem i na pierwszy rzut oka mogłaby się wydawać swego rodzaju zdradą czy zaprzeczeniem podjętej wcześniej drogi. Rzeczywiście wielu autorów, dawnych i wspólczesnych, zastanawiało się nad motywami, które sprawiły, że młody Chryzostom powrócił do wcześniejszej formy życia. Co więcej, uważa się - idąc śladem relacji Palladiusza - że to warunki fizyczne Jana nie wytrzymały próby pustyni.

Za najbardziej satysfakcjonującą interpretację uważam proponowaną przez Ottorino Pasquato, jednego $\mathrm{z}$ najbystrzejszych badaczy Chryzostoma

Matteo, I, Roma 2003, 5-29 (miejsce i data powstania Homilii na Ewangelię Mateusza, aspekty egzegetyczne, tematyka przepowiadania Chryzostoma w tychże Homiliach, wydania, tłumaczenia, opracowania).

${ }^{3}$ Dla pogłębienia tych kwestii zob. E. Dal Covolo (red.), Storia della teologia, I: Dalle origini a Bernardo di Chiaravalle, Bologna-Roma 1995, 181-203 (Esegesi biblica e teologia tra Alessandria e Antiochia) i s. 520, przypis 11. W szczególności o „teologii antiocheńskiej” zob. bibliografię wskazana przez L. Zappella (red.), Giovanni Crisostomo, Le catechesi battesimali (= Letture cristiane del primo millennio 27), Milano 1998, 129-138, do niej dodam pracę D.S. Wallace-Hadrill, Christian Antioch. A study of Early Christian Thought in the East, Cambridge 1982: por. także E. Dal Covolo, Le catechesi battesimali di san Giovanni Crisostomo. „Salesianum” 63 (2001) 157-167.

${ }^{4} \mathrm{Na}$ temat monastycyzmu w Antiochii zob. L. Zappella (red.), Giovanni Crisostomo, s. 61-63. 
w naszych czasach, wyrażoną w jednym $\mathrm{z}$ artykułów dotyczących tej kwestii 5 . Jego zdaniem, historia powołania Jana nie zanotowała żadnego przełomu podczas sześciu lat spędzonych na pustyni. Właśnie przez samotną lekturę i kontemplację Słowa Bożego, Chryzostom odkrył nieodpartą i naglącą potrzebę głoszenia tego właśnie Słowa na pożytek i dla zbawienia drugich. Potwierdza to fakt, że ledwie powrócił do Antiochii, podjął z całkowitym oddaniem swą służbę Słowu; na nowo włączony między lektorów, wyświęcony na diakona i ostatecznie zostaje kaplanem.

W tej perspektywie może być odczytany także słynny Dialog z Bazylim, zredagowany około $390 \mathrm{r}$. (to znaczy w tym samym czasie, co Homilie na Ewangelię Mateusza) ${ }^{6}$, gdzie Jan Chryzostom mówi o „dobrym przykładzie” i o „słowie” jako lekarstwach prezbitera:

„Lekarze ludzkich ciał wynaleźli wiele lekarstw [...]. Tutaj zaś nic podobnego nie można wymyślić. Poza dobrym przykładem jeden tylko pozostaje środek, jedna droga do wyleczenia - pouczenie przez słowo"7.

W tym samym Dialogu Chryzostom mówi o kapłaństwie jako o „życiu pełnym odwagi i poświęcenia", bo urząd (prawdziwego) pasterza nie zna ciasnych granic własnej opłacalności, ale obraca się zawsze na korzyść całej owczarni. Troska o owczarnię jest, jego zdaniem, „znakiem miłości” i najwymowniejszym dowodem tego, że pasterz miłuje prawdziwie Pana: „Jeśli mnie miłujesz, paś owce moje...". Przy tej okazji, zauważa Chryzostom, że Mistrz zapytał ucznia, czy go miłuje, nie po to, aby zasięgnąć wiedzy na ten temat; wszak przenika i zna serca wszystkich:

„Nie chodziło mu wtedy o pokazanie, jak go Piotr miłował: było to juz nam znane $z$ wielu innych miejsc; lecz chciał pouczyć Piotra i nas wszystkich, jak on (Pan nasz) kocha swój Kościół, abyśmy i my z całą gorliwością oddali się na jego służbę"9.

Właśnie ze względu na tę gorliwość duszpasterską, głęboko związaną ze służbą Słowu, Chryzostom opuścił pustynię, by zostać kapłanem.

${ }^{5}$ Por. O. Pasquato, Ideale sacerdotale e formazione al sacerdozio del giovane Crisostomo: evoluzione o continuità?, w: S. Felici (red.), La formazione al sacerdozio ministeriale nella catechesi e nella testimonianza di vita dei Padri (= Biblioteca di Scienze Religiose 98), Roma 1992, 59-93: E. Dal Covolo, Sacerdoti come i nostri Padri. I Padri della Chiesa maestri di formazione sacerdotale, Roma 1998, 35-40.

" Por. F. Marinelli, La carta del prete. Guida alla lettura del «Dialogo sul sacerdozio» di San Giovanni Crisostomo, Roma 1986; M. Lochbrunner, Uber das Priestertum. Historische und systematische Untersuchung zum Priesterbild des Johannes Chrysostomus (= Hereditas. Studien zur Alten Kirchengeschichte 5), Bonn 1993.

${ }^{7}$ Dialogus de sacerdotio IV 3, 5-13, SCh 272, 248-250.

${ }^{8}$ Por. tamże II 4, 51-64, SCh 272, 116-118 (odniesienie dotyczy przede wszystkim wyrażenia ghennaia psyché w znaczeniu, jakie przyjmuje w słownictwie chrześcijarískim, a w szczególności u Chryzostoma, zob. tamze, s. 117, przypis 3).

${ }^{9}$ Tamże II 1, 35-40, SCh 272, 102. 
Lata kapłaństwa antiocheńskiego, między rokiem 386 i 397, były zapewne najszczęśliwszymi $w$ jego życiu. $Z$ posłania biskupa (przypadek raczej rzadki w pierwszych wiekach Kościoła, żeby biskup był doktorem i kaznodzieją swojej diecezji), Chryzostom oddaje się całkowicie temu przepowiadaniu, co miało na zawsze stanowić o jego sławie. Słynne Homilie Chryzostomowe wiernie odzwierciedlają pasterską gorliwość, dla której Jan opuścił pustynię. W wyjaśnianiu Pisma św. pozostanie zawsze przywiązany do konkretnych problemów swoich słuchaczy. Pod tym kątem, jego egzegeza typowo antiocheńska, wydaje się pod wieloma aspektami być komplementarną dla egzegezy Klemensa, Orygenesa i wielkich mistrzów aleksandryjskich.

W szczególności, Jan musiał zmierzyć się z ogromnymi problemami Antiochii, prawdziwcj ,,metropolii” starożytności. Licząca między 150.000 a 300.000 mieszkańców Antiochia, była po Rzymie i Aleksandrii trzecim najgęściej zaludnionym miastem imperium rzymskiego. Ówczesne problemy nie różnity się wielce od problemów wspólczesnych metropolii: korupcja, klientelizm, i jak mówią Włosi - „tangentopoli”..., a przede wszystkim groźne zróżnicowanie między bogatymi i bicdnymi. W tej sytuacji Chryzostom jest bez ustanku mobilizowany do podejmowania różnorodnych problemów, powstających w życiu wspólnotowym bogatych i ubogich ${ }^{10}$; wystarczy pomyśleć, że w samych tylko Homiliach na Ewangelie Mateusza ten temat powraca nie mniej niż sto razy! Faktem jest, że Chryzostom poczytuje za skandal nie do zniesienia obojętność bogatych chrześcijan wobec braci potrzebujących. I wciąż przychodzi mu wołać, wraz z Pismem św., którego stał się sługą: „Byłem głodny, a nic daliście mi jeść" (zob. Mt 25, 31nn.).

Na tym poprzestanę, jeśli chodzi o doświadczenie życia Chryzostoma i jego kontekst historyczno-teologiczny. Znamy dobrze tragiczny epilog. W 397 r. Jan został wybrany na katedrę patriarchy Konstantynopola, gdzie napotkał zazdrość i niezrozumienie, które nie miały sobie równych. Wycieńczony cierpieniem zmarł w drodze, w Komana w Pityoncie, podczas gdy pieszo zmierzał do celu swego ostatnicgo wygnania; było to 14 września 407 roku.

\section{HOMILIA 50 NA EWANGELIE MATEUSZA}

Homilie na Ewangelię Mateusza są najstarszym komentarzem do pierwszej Ewangelii, jaki posiadamy. Przedstawiają one także znaczące świadectwo tej aktywności homiletycznej ${ }^{11}$, która zapewniła Chryzostomowi najwyższe uzna-

${ }^{10}$ Por. S. Zincone, Ricchezza e povertà nelle omelie di Giovanni Crisostomo, L'Aquila 1973; A. Olivar, I poveri alle porte delle chiese nella predicazione del IV secolo, w: E. Manicardi F. Ruggiero (red.), Liturgia ed evangelizzazione nell'epoca dei Padri e nella Chiesa del Vaticano II. Studi in onore di Enzo Lodi, Bologna 1996, 219-235.

1 Na temat przepowiadania Chryzostoma por. O. Pasquato, Giovanni Crisostomo, w: M. Sodi - A.M. Triacca (red.), Dizionario di Omiletica, Gorle 1998, 648-655 (z bibliografią). 
nie wśród oratorów cklezjalnych. Sięgają one czasu między rokiem 386 a 397 (prawdopodobnie 390), to znaczy między święceniami kapłańskimi w Antiochii a wyborem na katedrę patriarchy Konstantynopola, czas, w którym Chryzostom podejmował zadania kaznodziei w najważnicjszych kościołach antiocheńskich. Służba ta w szczególny sposób odpowiadała Janowi, który po doświadczeniach monastycznych i pustelniczych przyjąl kapłaństwo wypełniając powotanie duszpasterskie, któremu nie podobna było się oprzeć, i które właśnie przez przepowiadanie Pisma św. pragnąl realizować: ściśle związane ze sobą przepowiadanie i egzegeza - wierne podstawowym wskazaniom „szkoły antiocheńskiej" - wydają się być szczególnie wyczulone na konkretne sytuacje życiowe, na problemy i potrzeby także materialne swoich słuchaczy.

Owe wskazania egzegetyczne i duszpasterskie, tak charakterystyczne dla przepowiadania Chryzostomowego, odzwierciedlają się dokładnie w Homilii 50 na Ewangelię Mateusza, i wyjaśniają jej swoistą budowę. Jak wspomnieliśmy na początku, Homilia komentuje perykopę zamykającą 14 rozdział Ewangelii Mateusza. Tematy rozwinięte w pierwszych dwóch paragrafach, poświęconych dokładnej egzegezie ww. 23-36, to przede wszystkim modlitwa, cierpliwość pośród prób, pedagogia Boga i wiara uczniów. W rzeczywistości jednak wyjaśnienie wersetu 36 przedłuża się na dwa następne paragrafy, trzeci i czwarty, zapełniając ponad połowę całej Homilii. Owo poszerzenie tłumaczy się kontekstem liturgii eucharystycznej, w której ma miejsce homilia:

,Dotknijmy i my frędzli Jego plaszcza, co więcej, jeśli chcemy, mamy Chrystusa całego. Jego ciało jest teraz prawdziwie przed nami. Nie tylko płaszcz, ale jego ciało: nie tylko by go dotknąć, ale by jeść i być nasyconym... Cóż że nie słyszysz jego glosu? Kontemplujesz go na oltarzu; i co więcej, słyszysz także jego glos, jako że mówi do ciebie przez ewangelistów"12.

Odtąd Homilia koncentruje się w całości na temacie Eucharystii i dyspozycji moralnej koniecznej dla godnej jej celebracji. Tak też kontynuuje Chryzostom:

„Wierzycie, że także teraz mamy ten stól, przy którym Jezus zasiadł z apostołami. Nie ma żadnej różnicy między ostatnią wieczerzą a ucztą oltarza [...]. Trzeba, byśmy wszyscy dobrze zrozumieli, kapłani i wierni, jakim darem Pan zechciał nas obdarzyć, i do jakiej godności nas wyniósł. Rozpoznajmy ją i zadrżyjmy. Chrystus pozwolil nam nasycić się swoim cialem, ofiarowal nam samego siebie (poświęconego w ofierze). Jakie znajdziemy usprawiedliwienie, jeśli tak nasyceni będziemy grzeszyć, jeśli nakarmieni Barankiem żyjemy jak wilki; jeśli żywieni takim pokarmem, nie przestanicmy być chciwi jak lwy? Ten sakrament wymaga nie tylko, byśmy byli zawsze wolni od przemocy i lapczywości, ale czyści także od wszelkiej skazy nieprzyjaźni. Ten sakrament jest przecicż sakramentem pokoju, i nie pozwala na przywiązanie do bogactwa"13.

${ }^{12}$ In Matthaeum hom. 50, 2, PG 58, 508.

${ }^{13}$ Tamże 50,3, 507-508. 


\section{I oto ostatecznie punkt docelowy Homilii:}

„Aby żaden Judasz nie zbliżał się do stołu!" - woła Chryzostom. I nie jest odpowiednim kryterium godności to, by przychodzić do oltarza ze złotymi kielichami: „Nie był stół ze srebra, ani kielich ze złota, z którego Chrystus dał uczniom swoją krew [...]. Pragniesz czcić Ciało Chrystusa? Nie lekceważ go, gdy jest nagie, i nie oddawaj mu czci w świątyni suknem z jedwabiu, aby lekceważyć je potem na zewnątrz, gdzie doświadcza zimna i nagości. Ten, który powiedział: «To jest ciało moje », jest tym samym, który rzekl: «Byłem głodny, a nie daliście mi jeśćs i «Wszystko, co uczyniliście jednemu z tych braci moich najmniejszych, mnieście uczynili». Nauczmy się więc mądrości i czcić Chrystusa tak, jak on tego chce, dzieląc bogactwa między biednych. Bóg nie potrzebuje złotych sprzętów, ale złotych dusz. Po co stól eucharystyczny zastawiony złotymi kielichami, kiedy on umiera $z$ głodu? Zacznij karmić go glodnego, a potem $z$ tego, co zostanie, będziesz mógl ozdobić również ołtarz!"14.

\section{WNIOSKI KOŃCOWE}

Oto kim jest Judasz, według Chryzostoma: to ten, co zbliża się do Ciała i Krwi Pana, alc w rzeczywistości nie podziela projektu jego życia. Jan, zawsze czuły na konkretne skutki i wagę spoleczną decyzji wiary, nie traci okazji by podkreślać to z mocą, nawet za cenę uczynienia swej Homilii „pełną dysproporcji”. Nie przypadkiem więc Jan Paweł II, w swej najnowszej Encyklice Ecclesia de Eucharistia, w części poświęconej wpływowi Eucharystii na życia społeczne i polityczne chrześcijan, cytuje właśnie Chryzostomową Homilię 50 na Ewangeliq Mateusza:

„Znaczącą konsekwencją tego wpisanego w Eucharystię ukierunkowania ku eschatologii jest równicż fakt, iż w naszej dziejowej wędrówce daje ona impuls i zasiewa żywe ziarno nadziei w nasze codzienne zadania i obowiązki. To, że chrześcijańska koncepcja prowadzi nas ku «nowemu niebu» $\mathrm{i}$ «nowej ziemi», nie oslabia naszego poczucia odpowiedzialności za tę doczesna ziemię, raczej je rozbudza. Pragnę z całą mocą przypomnieć to na początku nowego tysiąclecia, ażeby chrześcijanie czuli się bardziej niż kiedykolwiek wezwani, aby nic zaniedbywać obowiązków przynależnych mieszkańcom tej ziemi [...]. Jest wiele problemów, które zaciemniają horyzont naszych czasów. Wystarczy wspomnicć pilną potrzebę pracy na rzecz pokoju, troskę o budowanie w stosunkach międzynarodowych trwalych fundamentów sprawiedliwości i solidarności, obronę życia ludzkiego od poczęcia aż do jego naturalnego końca. A co powiedzicć o tysiącach sprzeczności «zglobalizowanego» świata, w którym najsłabszym, najmniejszym i najuboższym może się wydawać że niewiele mają powodów do nadziei? [...]. Również po to Pan chciał pozostać z nami w Eucharystii, wpisując w swoją ofiarną i braterską obecność obietnicę ludzkości odnowionej Jego milością [...]. Również apostoł Paweł, uznaje za «niegodnc» 
wspólnoty chrześcijańskiej uczestnictwo w Wieczerzy Pańskicj, jeśli jest ona sprawowana w sytuacji podziału i obojętności wobec ubogich"15.

I właśnie w tym miejscu, w przypisie, Papież przywołuje Chryzostomową Homilię, już uprzednio raz przez niego wspomnianą w Sollicitudo rei socialis ${ }^{16}$.

U korzeni tych zapewnień leży całkowicie pelna identyfikacja Chrystusa z ubogimi, wciąż przywoływana przez Chryzostoma na kanwie Ewangelii Mateu$s z a$. Istotnie, konkretna i prosta praktyka milości wobec ubogich okazuje się być milością do Chrystusa. „Co mówi w rzeczywistości Jezus?”, zapytuje się Chryzostom, zbliżając się już do końca Homilii. I odpowiada cytując Mateusza 26, 11:

„ «Albowiem zawsze ubogich macie u siebie, lecz mnie nie zawsze macie». Przede wszystkim z tego powodu musimy być miłosierni: nie zawsze będziemy mieć Chrystusa głodnego pośród nas, ale będziemy go mieli takim tylko w tym życiu [...]. Zechciejmy czytać i dobrze poznać wszystkie prawa i zasady zawarte w Starym i Nowym Testamencie dotyczące jałmużny, i wypełniajmy je $z$ wielkim zapałem. Hojność wobec biednych oczyszcza z grzechu"17.

Należy jednocześnie dodać, że owa miłość bliźniego, by była rzeczywiście tą Jezusową miłością - musi żywić się komunią z Bogiem i jego miłością dla nas. U źródła osobliwego rozwinięcia egzegetycznego Homilii 50 leży „krawędź (frędzle) płaszcza", i zaproszenie by zbliżać się z wiarą do Jezusa Chrystusa. Zresztą w swoim przepowiadaniu Chryzostom $\mathrm{z}$ naciskiem podkreśla głęboką więź istniejącą między przykazaniem miłości i życiem Bożym. Innymi słowy, by wzrastać w autentycznej milości, trzeba znać Jezusa, żyć w jego bliskości. Podobnie jak w Dialogu o kaptaństwie, jego mowa powraca do „wymiaru kontemplacyjnego" życia i do jakości spotkania z Panem w Słowie i sakramentach.

tłum. Krzysztof Charamsa

\section{OMELIA 50 SUL VANGELO DI MATTEO DI GIOVANNI CRISOSTOMO}

(Disproporzione dell'esegesi)

${ }^{15}$ Ecclesia de Eucharistia 20.

${ }^{16}$ Por. E. Dal Covolo, I Padri della Chiesa e la Sollicitudo Rei Socialis, w: M. Toso (red.), Solidarietà. Nuovo nome della pace. Studi sull'Enciclica "Sollicitudo rei socialis" di Giovanni Paolo II, Torino 1988, 15-27.

${ }^{17}$ In Matthaeum hom. 50, 4, PG 58, 510. 